\title{
Agenda for Winter Business Meeting 1999
}

\author{
The Royal College of Psychiatrists' \\ Winter Business Meeting is to be \\ held at $5.30 \mathrm{pm}$ on 3 February 1999 at \\ the Royal College of Psychiatrists. \\ The President, Dr Robert Kendell, \\ in the Chair. \\ Agenda
}

1. To approve the Minutes of the previous Winter Meeting held at the Royal Lancaster Hotel, London on 22 January 1998, see p. 55.

2. Obituary.

3. Election of Honorary Fellows

Professor Charles Anthony Butterworth Professor Butterworth has been central to the development of community psychiatric nursing as an academic discipline over the past 15 years, and has always striven hard for intellectual recognition of his subject area. His background is in both mental health and general nursing, and he has practised, taught and researched both in hospitals and the community. Professor Butterworth is director of the World Health Organization's Collaborating Centre for Reference Research and Education in Primary Health Care. He has been central in the development and evaluation of methods of training nurses in psychosocial interventions, a training package which is now being promoted nationally in the UK (the Thorn Initiative).

Dr Jerome H. Jafie

Dr Jaffe first showed his flair for researchbased policy development as Director of the State of Illinois Drug Abuse Programme. In 1971, he was called to Washington to take on the directorship of the Special Action Office for Drug Abuse Prevention set up by President Nixon within the White House. In this post, he provided a model of design and actualisation of a national drugs policy which has been of great significance throughout the world. Dr Jaffe's contributions to research have included basic and applied work on treatment of opiate dependence with substitute drugs. Most recently, he has been a member of the College's working party making recommendations on drug policy.

Professor William Alwyn Lishman

Professor Lishman is the foremost expert on neuropsychiatry in the world. His great text- book, Organic Psychiatry - the Psychological Consequences of Cerebral Disorders has just appeared in its 3rd edition, and been completely revised so that it now includes the latest references to a rapidly expanding field. His own contributions, to cerebral injury, to the cerebral effects of alcoholism, and to epilepsy, have been distinguished. It is not too much to say that Professor Lishman created the subject of neuropsychiatry as we now know it. He has trained many psychiatrists in this country and abroad, and few of those who practise as neuropsychiatrists can have failed to have been influenced by his teachings.

\section{Baron Rix of Whitehall and City of Westminster}

Lord Rix has had a long and distinguished record in improving the lives of people with learning disabilities. He achieved great fame through working in the theatre and has used that influence to many positive and humanitarian effects. Mencap headed by Lord Rix. takes a lead in multi-agency working and has always recognised the mental health needs of people with learning disability. Lord Rix has been particularly supportive of the Journal of Intellectual Deficiency Research, owned by Mencap, which publishes many papers by members of the Faculty of Learning Disability. He has promoted a proper medical study of learning disability with compassion as well as science.

\section{Professor Robert Anderson Wood}

Professor Wood became the Lead Dean for Psychiatry in the early stages of the implementation of the 'Calman' reforms. He was particularly supportive of the Royal College of Psychiatrists over the transition to the specialist registrar grade. In addition. Professor Wood has taken a great interest in the development of training opportunities for women doctors, and this issue is particularly relevant to psychiatric training where there is a relatively high proportion of female trainees. He has contributed at a national level to postgraduate training on COPMeD, convening the working party on national documentation for preregistration house officer post-approval, and pre-registration house officer appraisal.

4. Report of the Registrar.

5. Resolutions (if any). 